\title{
Much ado about nothing? The controversy over the validity of the Coase theorem
}

\author{
Elodie BERTRAND ${ }^{1}$
}

This is the author's version of an article published in The European Journal of the History of Economic Thought 26(3), 2019, 502-36, available online at https://doi.org/10.1080/09672567.2019.1622752

\begin{abstract}
The controversy over the theoretical validity of the 'Coase theorem' is closely linked to the controversy over the correct statement of it, since the principal need is to determine what valid generalizations can be made on the basis of Coase's 1960 examples. The present article does not aim to review the content of the controversy as such, but rather to question the reasons behind it: why so much noise about a proposition that is patently unrealistic (because of its assumption of zero transaction costs)? I argue that the prominence of the controversy, namely of the question of the validity (and statement) of the 'Coase theorem', can be analytically explained by the roles this 'theorem' plays in microeconomics: it is critical (of the standard theory of market failures), heuristic (drawing out the consequences of the efficiency assumption), and normative (conveying an optimistic view of the efficiency of exchange). I stress that these roles depend on the nature of the exchange defined in the formulation of the 'theorem'. And I conclude that they rest upon the cooperative bargaining version, and therefore on an optimistic belief in the ability of people to find efficient agreements.
\end{abstract}

JEL Codes: B21, B25, D62, K00

Keywords: Coase theorem, externalities, bargaining

The lawyers said oh yes it's [the Coase theorem] a good idea and they tried to use it. The economists, some of them said it was a good idea and some of them said it was a bad idea and they quarrelled. (Coase 2002)

\section{Introduction}

The controversy over the validity of the 'Coase theorem' has mobilized numerous economists as well as lawyers: it is closely linked to the debate over its correct statement, since it consists in determining what valid generalizations can be made on the basis of Coase's (1960) examples. The present article will not review the content of the multiple proofs and refutations

\footnotetext{
${ }^{1}$ CNRS \& University Paris 1 Panthéon-Sorbonne (Institut des Sciences Juridique et Philosophique de la Sorbonne, UMR 8103), Elodie.Bertrand@univ-paris1.fr. Previous versions of this paper were presented at the ESHET Conference (Paris, May 2016) and the workshop of the Charles Gide Association (Paris, November 2015). I have benefited from comments and suggestions by the participants, especially André Lapidus and Nicola Giocoli, and by Andrew Halpin and Franz Dietrich. Two anonymous referees helped a great deal in tightening this paper's argument.
} 
of the different 'theorems' (for which see Medema and Zerbe 2000, the collection by Posner and Parisi 2013, and Medema 2019b), but will rather question why there is a controversy at all: why so much noise about a proposition that is plainly judged unrealistic because of its assumption of zero transaction costs? Why this controversy which, as Steven Medema wrote $(2011 \mathrm{~b}, 7)$, is 'an exercise whose theological equivalent is the question of how many angels can dance on the head of a pin'?

First, there are historical reasons. The controversy over the validity of the 'Coase theorem' is due to the multiplicity of its statements, which is in turn due to the 'looseness' of Coase's original text (Medema 2017b, 10). There is indeed no demonstration in Coase's original article, which concludes from a series of examples that '[i]t is necessary to know whether the damaging business is liable or not for damage caused since without the establishment of this initial delimitation of rights there can be no market transactions to transfer and recombine them. But the ultimate result (which maximises the value of production) is independent of the legal position if the pricing system is assumed to work without cost' (Coase 1960, 8). This is Coase's closest formulation of what would be called the 'Coase theorem' by Stigler $(1966,113) .^{2}$ There have since been as many 'Coase theorems' as there have been interpretations of Coase's idea and examples.

A second set of reasons for this controversy is contextual. As early as the 1960s, the 'Coase theorem' greatly contributed to the emergence and development of environmental economics (linked to a growing social concern for pollution) and the economic analysis of law (Medema 2017b, 43-44; see Medema 1999 and 2014f).

Third, ideological reasons could explain the vigour of this controversy, the 'theorem' being used to justify or being blamed for justifying both liberal and socialist policies (Medema $2011 \mathrm{~b}, 11){ }^{3}$

The present article will focus on another reason, this one analytical. I shall argue that the controversy over the 'Coase theorem', namely the importance of the question of the validity (and proper statement) of this proposition, can be explained by the roles this 'theorem' plays in microeconomics - that is, as critical (of the standard theory of market failures), heuristic (drawing out the consequences of the efficiency assumption), and normative (conveying an optimistic view of the efficiency of exchange). And I proceed by questioning the theoretical meaning of the different statements of the 'theorem' and their roles.

I have already argued in this journal (Bertrand 2010) that the 'Coase theorem' played three roles in Coase's own works: critical (of the Pigovian tradition, its analysis and policy proposals), heuristic (bringing to light the influence of transaction costs), and normative (in the sense that prescriptions derived from it are based on the belief in the relative efficiency of the 'price system'). Most of the important articles in this controversy recognize the unrealism of

\footnotetext{
2 On the early reception of 'The problem of social cost', see Marciano and Medema 2011; Medema 2013; 2014a; $2014 \mathrm{~b} ; 2014 \mathrm{e}$.

3 For example, it is charged by Samuels $(1974,27)$ with being 'part of the apologetics and theology of the market and of private property', and, on the contrary, by Block, Callahan and Barnett (2005) as being against market and private property. Randall wrote in 1974: "At almost every stage in the debate which sprang up around "The Problem of Social Cost," it is unclear whether theory fathered policy viewpoints, or vice-versa. That surely accounts for the fascination which the Coasian debate has held for a sizeable number of academic economists. It has the stuff of which great scholarly debates are made - opportunity for high powered theorizing possibly leading to, or justifying, radical suggestions for policy re-orientation' $(1974,36)$.
} 
the assumption of zero transaction costs, ${ }^{4}$ and justify their interest in the 'theorem' by reference to the very roles already cited in Coase (be it to refute or to confirm them). However, these articles also extend, clarify, and modify these roles. I shall use the same categorization of these roles as in my previous article (2010), but interrogate their meaning in the debate over the 'theorem' as well as their consistency with the formulation of the 'theorem' that is chosen. I will stress that the meaning and scope of these roles depend on the formulation of the 'theorem' that is selected. And I will argue that the version that best supports these three roles is the cooperative bargaining one, which itself rests on an optimistic view of the agents' ability to find an efficient agreement.

Other roles of the 'theorem' could be identified. It is sometimes viewed as a predictive proposition (which can be tested), or as a prescriptive one (which implies lowering transaction costs or mimicking the market). However, as noted by Medema (2017b, 40), the 'theorem' itself cannot have these roles since it is a logical proposition of the form 'if... then', and since it assumes zero transaction costs, which is a condition that is never met. Medema (ibid., 41) hence analyses the theorem as a 'benchmark', serving to bring to light things unseen before, and to show what happens when some assumptions are relaxed. He also identifies these predictive, prescriptive, and benchmark views in the uses of the 'Coase theorem' for the analysis of law, environment, finance, organizational theory, politics, etc. In the present article, I focus on the meaning of the logical proposition itself, and not when we relax one of its assumptions. I examine the significance of proving and disproving the various particular statements of the 'theorem'.

This is why I focus on the efficiency thesis, which poses more interpretation problems than the independence thesis (furthermore, the latter depends on the former). Also, I only focus on those 'Coase theorems' that concern externalities. These 'theorems' have in common that they assume zero transaction costs (and allocated well-defined property rights ${ }^{5}$ ), and conclude that the result is efficient, even in the presence of externalities. They differ in the manner in which they envisage how we move from the initial situation (suboptimal because of externalities) to the (optimal) final situation, that is, in the way they envisage the process of exchange. Since, moreover, I am interested in the controversy over its general validity, but not in all the specific uses of the 'Coase theorem', I focus on some of the important articles of that controversy - and not on all the articles that mention the 'theorem' - and I examine the nature of the exchange and its efficiency. ${ }^{6}$

Analysing the controversy from this point of view leads to two insights. First, from a methodological perspective, it shows that the interest of a controversy does not necessarily lie in giving an answer to it. Since, in the case at hand, validity is a matter of interpretation and of belief, there is no definite answer here. But the controversy has indeed restated the terms of the debate. The different statements of the 'theorem' I identify pose these terms differently, formalizing the conditions under which exchanges on externalities could be efficient. In this

\footnotetext{
${ }^{4}$ For example, Regan 1972, Zerbe 1980, Schweizer 1988, Hurwicz 1995, Usher 1998, and McKelvey and Page 1999.

5 In a certain tradition, the zero-transaction-costs assumption implies that property rights are complete and perfect (since Allen 1991 and Barzel 1989). On the contrary, Demsetz (2011) recently built his criticism of Coase on the distinction between transaction costs and the 'costs of ownership', which are the costs of maintaining a system of private property rights (costs on which Coase would insist more in his 1959 article than in that of 1960).

${ }^{6}$ Note that the formalization of the exchange is also a formalization of the assumption of zero transaction costs.
} 
sense, the controversy on the 'Coase theorem' has posed anew one of the unsolved questions of economic theory, namely the question of exchange. And the answer lies outside the debate on the 'Coase theorem' proper.

This leads to the second interest of this controversy, which is theoretical. What it posed anew is the terms of the debate on the nature and efficiency of exchange: 'The Coase theorem is a proposition not only about externalities and their remedies, but also about the efficiency of bargaining in general' (William Samuelson 1985, 324). The value of the 'Coase theorem' is that it reasserts the efficiency of the market, an efficiency that was demonstrated inside highly restrictive limits (with the first theorem of welfare economics). But it issues in a trenchant result compared to general equilibrium theory: at least some of the conditions that were thought to be indispensable for efficiency were not. This is why I focus on the 'Coase theorems' as theories of exchange.

And this is why I first examine their critical role: they convey a strong criticism of welfare economics. If the 'Coase theorem' is formulated as assuming perfect competition (e.g., Starrett 1972; Zerbe 1980), it shows that the first theorem of welfare economics can be extended to externalities. But this formalization, suggested by Arrow (1969), is precisely the opposite of Coase's own solution. The role of the 'theorem' as critical of welfare economics is better supported by the version that assumes cooperative bilateral bargaining (e.g., Calabresi 1968; Hurwicz 1995). This version, closer to Coase's own examples, asserts that the strong assumptions of the perfect competition model are not necessary to conclude that the result of decentralized exchanges is optimal.

However, this formalization with cooperative game theory assumes that the result of bargaining is optimal, which makes it circular if the sole conclusion to be drawn from it is the efficiency of the result (when it exists). The interest of this circular version in fact lies in its heuristic role: to uncover all the consequences of the efficiency assumption, up to the disappearance of the traditional notions associated with externality, market failure, and Pareto optimality (e.g., Dahlman 1979; Calabresi 1991).

Defenders of this version believe in the efficiency of negotiation. I will underline the nature of this belief by contrasting this version with the third version, the non-cooperative one (proposed, for example, by Arrow 1979; Cooter 1982; Farrell 1987; McKelvey and Page 2002). The normative role of the Coase theorem is to convey this belief in the efficiency of exchange. And I shall argue that this normative dimension of the 'theorem' supports its critical and heuristic roles. I shall conclude that these roles - which are the analytical issues in the controversy over the 'Coase theorem' - rest upon the cooperative bargaining version, and therefore on an optimistic view of the ability of people to find efficient agreements. ${ }^{7}$

\section{The critical role: optimality with externalities, on which conditions?}

After the publication of 'The problem of social cost', some economists came to focus on Coase's 'result' (like Turvey 1963, Wellisz 1964, or Stigler 1966) for its criticism of the

\footnotetext{
${ }^{7}$ Medema (1999, 216-7; 2009, ch 7) and Medema and Zerbe (2000, 876) also explain the fascination exerted by the 'Coase theorem' by reference to its critical role and prescriptive stakes, but they do not distinguish the different meanings of these roles as a function of the statements of the 'theorem'. See also Medema and Samuels 1997 (859) for some conjectures about the attractiveness of the 'Coase theorem', as well as Medema 2011b (10-11), Medema 2014c (251-2), and Medema 2017b.
} 
traditional analysis of externalities. ${ }^{8}$ The meaning of this critical role, however, needs some clarification. Either the 'theorem' assumes perfect competition and permits an extension of the conclusion of the first theorem of welfare economics to external effects. Or it assumes decentralized negotiations and concludes that bilateral bargaining over property rights is efficient when transaction costs are nil, which implies that the strong assumptions of the perfect competition model would not be necessary for optimality. Consequently, the nature of the exchange determines the content of the criticism that is levelled at microeconomics.

\subsection{Perfect competition: an internal criticism}

The internalization of externalities by the market can first be thought of in a perfect competition model (PC statement of Table 1, p. 22). This was the framework in which the concept of externality was discussed in the 1950s (Berta 2017, Medema 2017a). We find this assumption mentioned by Zerbe $(1980,86)$ : 'Zero transactions costs thus means the perfect information and frictionless markets of perfect competition.' This interpretation of Coase's zero transaction costs world also appears in Starrett (1972), Hurwicz (1995), Boyd and Conley (1997), and Fox (2007). If this assumption is made, the conclusion of the 'Coase theorem' is that of the first theorem of welfare economics, but applied to property rights rather than to physical resources. Boyd and Conley $(1997,390)$ note: 'The first welfare theorem can be viewed as a Coase theorem.' ${ }^{9}$ Here the 'theorem' internally criticizes the perfect competition model: the assumption of the absence of externalities would not be necessary to conclude to optimality.

The formalization of this statement of the 'theorem' originates from Arrow (1969); it is this formalization to which Zerbe (1980) and Medema and Zerbe (2000) refer, and which is used by Starrett (1972), Hurwicz (1995), and Boyd and Conley (1997). Arrow (1969) poses the problem of externality in terms of missing markets, 'the failure of markets to exist' (ibid., 148). Incompatible with the assumption of the universality of markets, externalities necessarily produce suboptimalities that must be corrected. Arrow demonstrates that by reinterpreting the commodity space to include personalized externality-commodities (characterized by both the agent who emits it and the agent who receives it), and by associating prices with these new commodities, then a system of equilibrium prices exists and is optimal: '[B]y suitable and indeed not unnatural reinterpretation of the commodity space, externalities can be regarded as ordinary commodities, and all the formal theory of competitive equilibrium is valid, including its optimality' (ibid., 146). The solution hence consists in re-establishing a complete system of markets, which includes so-called 'external' effects, by creating missing competitive markets.

\footnotetext{
${ }^{8}$ These first works by Turvey (1963) and Wellisz (1964), published in Economica, and which diffused the idea today called 'Coase theorem', closely associate Coase 1960, Buchanan and Stubblebine 1962 and Davis and Whinston 1962; three articles, however, that have different aims. Buchanan and Stubblebine (1962) put forward a typology of externalities based on the criterion of the existence of gains from trade; gains from trade, when they exist, are assumed to be realized by the negotiation, like in Coase 1960 (which is cited only at the end of the article and only for its criticism of Pigou and its independence thesis). Regarding Davis and Whinston (1962)'s article, while it is sometimes considered as the first formalization in terms of bargaining of the 'Coase theorem', it is yet not an interpretation of Coase 1960 (which is not cited), and even less a bargaining version of the 'theorem' since there is no negotiation between the two enterprises in their model. On these first articles that followed the publication of 'The problem of social cost', see Medema (2013). On Buchanan's analysis of externalities, see Marciano (2013).

${ }^{9}$ This idea is rather widespread, see for example Blaug $(2007,200)$ : '[T] he Coase theorem is nothing but the first fundamental theorem of welfare economics in disguise' - but neither the assumption of perfect competition nor the model of exchange is explicit.
} 
This involves not only creating property rights on each of these personalized externalitycommodities, but also setting a unique price for each of these goods that is parametric for agents, in accordance with Arrow and Debreu's (1954) model. ${ }^{10}$ Consequently, 'since we are now assuming a market for pollution, (formally) there are no externalities present in this economy' (Hurwicz 1995, 55).

This interpretation encounters two main problems. On the one hand, the extension of the assumptions of the Arrow-Debreu model to externalities is theoretically difficult. Arrow's (1969) article aims in fact at arguing that the features of externalities precisely prevent the formation of bilateral markets for externality-commodities. First, the price-taking assumption is especially ill-suited to personalized externalities that have only one seller and one buyer (ibid., 146; see also Laffont 1978, 365, fn 14). Secondly, these externalities may not be appropriable in general. ${ }^{11}$ Thirdly, another assumption incompatible with the presence of negative externalities is the assumption of convex production sets, as demonstrated by Starrett (1972) and Laffont (1978) (but see Cooter 1980, Boyd and Conley 1997, and Conley and Smith 2005).

On the other hand, this statement of the 'theorem' faces another difficulty: it cannot present itself as an interpretation of Coase's decentralized solution, since Arrow precisely opposes his solution to Coase's. Arrow's solution demands a level of governmental intervention that is more significant than the mere definition and allocation of property rights as in Coase's solution. As he insists, Coase argues 'that in principle clear definition of property rights is sufficient to ensure efficiency. This position goes well beyond the standard neoclassical position that competitive markets suffice for efficiency. As is well known, defined property rights are only one of the necessary conditions for competitive markets' (Arrow 1979, 24). Arrow's solution by competitive markets calls for the institution of a perfectly competitive market for each bilateral externality, that is, as for any other market, an auctioneer and the pricetaking assumption. If the Coasean solution was so centralized, then it would not be opposed to Pigou's (1932) solution and its critical role would be called into question. ${ }^{12}$ Arrow's additional assumptions are absent from 'The problem of social cost', since this article is suggesting another way to internalize externalities, and another model of exchange: bilateral bargaining.

\subsection{Bilateral bargaining: an external criticism}

The example of bilateral negotiation on which Coase's statement of the 'theorem' is based concerns a rancher whose cattle destroy a neighbouring farmer's crops. The rancher, liable for the damage caused by his cattle, signs an agreement with the farmer by which the latter

\footnotetext{
10 'The key points in the definition [of the competitive equilibrium] are the parametric role of the prices for each individual and the identity of prices for all individuals' (Arrow 1969, 135). For more details on Arrow's treatment of externalities, see Berta 2017, and for a comparison with Coase, see Berta and Bertrand 2014.

11 'Pricing demands the possibility of excluding nonbuyers from the use of the product, and this exclusion may be technically impossible or may require the use of considerable resources' (Arrow 1969, 146). It is here that Arrow cites the famous example of the lighthouse, later criticized by Coase (1974, 375-6, n. 43) (see Bertrand 2006).

${ }^{12}$ In Arrow's solution, one can interpret the equilibrium prices of the externality-commodities as taxes or subsidies, depending on whether they are negative or positive: Starrett writes for example that the vector of equilibrium prices, if it exists, 'defines both a competitive equilibrium in the artificial markets scheme and a system of supporting taxes', with the difference that with the tax, the victim is not compensated as with prices (Starrett 1972, 186-7, his emphasis; see also Meyer 1971). Cooter $(1982,28)$ also stresses that the role of the State in Arrow's solution (1969) is not lesser than in the Pigovian solution.
} 
abandons his cultivation in exchange for a payment of an amount comprised between the farmer's net profit and the amount of the damage: 'There is clearly room for a mutually satisfactory bargain' (Coase 1960, 4). Coase sets this bargaining process within a perfectly competitive environment - since the agents take the price of meat and wheat as given, but make the price of the externality. ${ }^{13}$ And, as usual with bargaining, the price is thus indeterminate: 'What payment would in fact be made would depend on the shrewdness of the farmer and the cattle-raiser as bargainers' (ibid., 5). The final result is optimal since all the mutually satisfactory bargains are assumed to be struck: '[I]f such market transactions are costless, such a rearrangement of rights will always take place if it would lead to an increase in the value of production' (ibid., 15). ${ }^{14}$ As Coase $(1988,160)$ himself recognized, this framework contains Edgeworthian features. ${ }^{15}$

The bilateral bargaining interpretation (BB statement of Table 1) of Coase 1960 and of the 'theorem' is the dominant one. Stigler's account $(1966,113)$, the first statement of the 'Coase theorem', falls within this tradition, since it is derived from the same example of cattle and crops as in Coase's paper, with agents who make the price of the externality and take the price of the other goods. ${ }^{16}$ It is also selected by Turvey (1963), Calabresi $(1965,729 ; 1968$, $68^{17}$ ), DeSerpa (1977), Dahlman (1979, 142), Hurwicz (1995) and Usher (1998). It is identified as corresponding to Coase, but called into question, by Regan (1972), Cooter (1982), Veljanovski (1982), Farrell (1987) and Schweizer (1988).

With this 'theorem', the concern is no longer an internal criticism of the perfect competition model. But while there is still a concern to criticize this model, this time it is in a much more radical way: as Arrow wrote, the restricting assumptions of this model would not be necessary to reach optimality. This is also stressed by Farrell, who selects the interpretation in terms of bargaining precisely because it is opposed to the perfectly competitive market: 'Its claim is that complete competitive markets are not necessary for efficiency. Rather, if the market outcome is inefficient, then people will get together and negotiate their way to efficiency' $(1987,113)$. He adds: 'Unlike the welfare theorem, it makes no strong assumptions

\footnotetext{
${ }^{13}$ Which is not without problems, as Wellisz $(1964,350-1)$, for example, notes.

${ }^{14}$ The Pareto-optimal allocations are identical with those that maximize the value of production (Kaldor-Hicks criterion) if compensations are actually paid and if there is no income effect - Coase (1960)'s implicit assumptions. 15 The interpretation of the 'Coase theorem' in the bargaining tradition raises the question of the relationship between Walrasian perfect competition and Edgeworthian large number competition. Edgeworth's conjecture, proved later as the 'limit theorem' (Debreu and Scarf 1963), indeed claims that if the number of agents of each type tends toward infinity, then the core of the economy is reduced to the allocations of Walrasian equilibria. However, the identity of these equilibria should not hide the differences in the two concepts of equilibrium and in the processes of exchange that lead to it: Walrasian price-taking in one case, Edgeworthian recontracting in the other (Hildenbrand and Kirman 1988; see Berta and Bertrand 2014). Hence it is necessary to distinguish between these two versions of the 'Coase theorem' in perfect competition and in bilateral bargaining.

16 This is why Stigler $(1966,113)$ cites the assumption of perfect competition ('under perfect competition private and social costs will be equal'); see Bertrand 2019. On Stigler and the 'Coase theorem', see also Medema 2011a and Marciano 2018

17 'If people are rational, bargains are costless, and there are no legal impediments to bargains, transactions will ex hypothesis occur to the point where bargains can no longer improve the situation; to the point, in short, of optimal resource allocation' (Calabresi 1968, 68). On Calabresi and the 'Coase theorem', see Marciano (2012) and Medema (2014b; 2014d).
} 
about convexity, price-taking, and complete markets. Instead, a one-line argument says that, absent barriers to contracting, all must be well!' (ibid., 114). ${ }^{18}$

The 'Coase theorem', as stated in the manner of Coase, Dahlman or Calabresi, may be formalized with cooperative game theory (statement $\mathrm{C}-\mathrm{BB}$ of table 1), which imposes a minimal condition on the selected solution concept: that of being optimal. There is a broad consensus on the relevance of this type of model in formalizing Coase's approach, since the latter presumes that bargainers will manage to find their way to the optimum. ${ }^{19}$ The final result is assumed to belong to the contracts curve, and more precisely to the core (Hurwicz 1995), but other solution concepts may be suggested as well, such as the Nash solution (Schweizer 1988; McKelvey and Page 1999). ${ }^{20}$ The problem is that, as was evidenced by formalization with cooperative game-theory (which characterizes the properties of the solution), the efficiency of the result is presupposed and not inferred. Since 'cooperative solutions are efficient by definition' (Schweizer 1988, 246), '[c] ooperative solution concepts are a way of illustrating the theorem but one which will never lead to a proof' (ibid., 254). ${ }^{21}$

\section{The heuristic role: the stakes of the efficiency assumption}

The 'Coase theorems' that assume efficient bilateral bargaining are circular, as Calabresi (1968, 68) recognizes concerning his own statement: 'Far from being surprising, this statement is tautological'. But why could not we do without circularity? In other words, why is it necessary to assume optimality? And, in this case, what is the use of the 'Coase theorem'?

\subsection{Why is the assumption of efficiency needed?}

The formalization with cooperative game theory defines the result as optimal, but does not provide any indication on how the agents attain it. The process of negotiation is not formalized: 'While the cooperative environment is relatively congenial to the Coase theorem,

\footnotetext{
${ }^{18}$ McKelvey and Page (1999, 237-8) convey a similar idea, but in the context of asserting that the 'Coase theorem' would be an extension, in a broad sense, of the first welfare economics theorem: 'One of the most fundamental theorems in economics (the First Welfare Theorem) claims that the competitive equilibrium which emerges from the private interactions of many individuals in a competitive model without externalities will be efficient. Now Coase was extending the claim of efficiency from private, self-interested maximization to include the efficient management of environmental harms (smoke). [...] Coase also made another startling claim - that this process of rights delineation and direct bargaining would lead to efficiency even when there were a small number of affected parties. [...] Coase's broad interpretation of the scope of his theorem, to include environmental problems, tort law, and small as well as large numbers, and the rapidly emerging agreement that Coase was right in this interpretation, helps explain much of the Coase Theorem's enormous impact on economics, law, and public policy. The Coase Theorem is the competitive model writ large.'

${ }^{19}$ Arrow $(1979,24)$ writes about Coase (1960): '[I]t appears that the basic postulate is the same one that underlies the theory of cooperative games [...]. That is, whatever else may be true about the outcome of the bargaining process, it will certainly be Pareto optimal.' Rob $(1989,308)$ also asserts: '[T]he Coase argument is more in the spirit of cooperative game theory where efficiency is being postulated as an axiom, rather than being shown to emerge as an outcome of some non-cooperative procedure.' And finally William Samuelson $(1985,324)$ views Coase's argument as being 'in the spirit of cooperative game theory.'

${ }^{20}$ The competitive solution is a specific point of the core, hence a specific point in the set of bilateral bargaining solutions (Varian 1995; McKelvey and Page 1999).

${ }^{21}$ While asserting that the solution is efficient is tautological since the solution has been defined as efficient, it remains to demonstrate that such a solution exists. That the core may be empty in some cases was first demonstrated by Aivazian and Callen (1981), who initiated a controversy which has endured until today (see for a review Medema 2017b, 24-25 and Aivazian and Callen 2017; see also Gonzalez and Marciano 2017, for an example of a recent contribution and the literature cited therein). Anyway, the core is not empty in the bilateral case in which Coase (1960) situates his examples.
} 
it deftly avoids the processes through which agents arrive at a solution' (Medema 2017b, 26). Now, as soon as we think about this process and not just about its result, nothing guarantees that bargaining between two individually rational agents will lead to an optimal result. The central problem of bargaining is the distribution of the exchange surplus. Each agent seeks to maximize her own part of the surplus, and not the social surplus. And if they do not agree on the distribution of this total surplus, the exchange, even if mutually beneficial, is not struck. This problem may arise even when information is complete and when transaction costs are nil: it is not sufficient that agents know that they could jointly attain a better situation to assert that they will. If they do not agree on the terms of the bargain, they will not attain that situation. Surely, at the moment an agreement is signed, it enhances efficiency, whatever the distribution of the surplus may be; but what matters is that agents find an agreement on this distribution, which is not self-evident, even with individual rationality, complete information, and no transaction costs. This is why Paul Samuelson, referring to Coase (1960), insists that:

the rational self-interest of each of two free wills does not necessitate that there will emerge, even in the most idealized game-theoretic situation, a Pareto-optimal solution that maximizes the sum of the two opponents' profits, in advance of and without regard to how that maximized profit is to be divided up among them. Except by fiat of the economic analyst or by his tautologically redefining what constitutes "nonrational" behavior, we cannot rule out a non-Pareto-optimal outcome. We can rule it out only by Humpty-Dumptyism. (Samuelson 1967, 35, his emphasis $)^{22}$

This criticism is also levelled at the 'Coase theorem' by, in particular, Regan (1972), Arrow (1979), Cooter (1982), Veljanovski (1982) and Coleman (1984). William Samuelson clearly poses the problem, isolating the conflict over distribution from other strategic behaviours due to an undetermined result or incomplete information:

The usual presentation of the Coase theorem omits the specifics of the bargaining process. The presumption is simply that such agreements [preferred by both sides] can and will be reached since it is in the joint interest of the parties to do so. Although this conclusion is appealing, it is considerably stronger than the economist's customary hypothesis of individual rationality. Even under perfect information, this presumption is far from obvious. Each individual seeks only to maximize his individual utility and does not seek a point on the utility-possibility frontier per se. (Samuelson 1985, 321-2, his emphasis)

This is why, in his view, the 'Coase theorem' has to assume that 'in the absence of transaction costs, the agents will strike mutually beneficial agreements' (ibid., 321).

Among defenders of the 'Coase theorem', three solutions emerge to the distribution problem:

1. To go back to the perfect competition interpretation. Zerbe, for example, infers from the fact that the bargaining interpretation poses problems like extortion that ' $[\mathrm{t}] \mathrm{o}$ even speak of

\footnotetext{
${ }^{22}$ Edgeworth (1881), for his part, was assuming that the agents accept every exchange that increases their utility, hence every mutually beneficial exchange whatever the surplus distribution may be, and without anticipating future movements (Berta 2000, 66). Samuelson reiterated his argument, for example in 1995.
} 
bargaining in a world of zero transactions costs is contradictory' $(1980,85)$ (while noting that this is what Coase himself does), and for this reason he selects the perfect competition interpretation.

2. Following William Samuelson, to make explicit, besides the zero-transaction-costs assumption, the assumptions of agreement upon the surplus distribution or exhaustion of gains from trade. This is the solution adopted, for example, by Hoffman and Spitzer: their statement of the 'theorem' adds the assumption that 'agents will strike mutually advantageous bargains in the absence of transactions costs' $(1982,73)$ because the zerotransaction-costs assumption does not rule out that '[p]arties can refuse to agree to the deal indefinitely' (ibid., 75, n. 8). The problem is that we then return to the circularity of the 'theorem'.

3. Finally, rather than adding the assumption of the exhaustion of gains from trade, it is possible to include it in the zero-transaction-costs assumption, which comes back to including strategic problems in the definition of these costs. This is done, for example, by Polinsky $(1979,3)$, for whom the assumption of zero transaction costs includes 'that they bargain cooperatively', or by Calabresi $(1991,1222)$ who details the implicit assumption of his 1968 statement: 'Winners and losers will successfully resolve arguments over the division of the gains (i.e., of the surplus), for absence of transaction costs means that they will work out all games so as to create that division of the gains that will maximize the surplus.' A similar idea is found in Usher - 'failure to agree is itself a transaction cost' $(1998,3)$ - who infers that ' $[t]$ he strictly-correct version of the Coase theorem boils down to the proposition if people can agree upon an efficient outcome, then there will be an efficient outcome' (ibid., 9). Here again, we fall back on a circular statement of the 'Coase theorem'; as Paul Samuelson would have said, we have ruled out sub-optimal results by Humpty-Dumptyism.

The necessity of the assumption of the exhaustion of gains from trade cannot be stressed enough: 'The Coase theorem dispenses with the heavy assumptions of perfect competition, but replaces them with the strong assumption that no mutually beneficial agreement is missed. So while it economizes on formal institutions, it demands a lot of coordination and negotiation' (Farrell 1987, 114).

\subsection{What is the use of this circular proposition?}

If the 'Coase theorem' is circular, and there is no demonstration of the efficiency of decentralized negotiation, its role as a criticism of the perfect competition model is weakened. The question thus remains: what is the use of building and defending a circular 'Coase theorem'? The answer is that it plays a heuristic role in, at least, three directions.

(i) First of all, formalizations of the 'Coase theorem' with cooperative game theory force the analyst to think about the solution concept selected, and enable her to pose three questions about the optimum.

(a) Starting from the multiplicity of solution concepts, which split the surplus in different ways, the question of the choice of the optimum puts the stress on the need for a theory of distribution, the attention then being focused on the choice of the solution concept and on the distribution it entails. 
(b) The second question, of existence, originates with Aivazian and Callen (1981), who demonstrated that the core may be empty with at least three players, and under one set of property rights (see fn 21 ).

(c) The third question is that of independence of the solution from the initial distribution of property rights. The cooperative framework allows one to formalize some conditions for the independence thesis to hold, such as those of quasi-linear preferences:

[W]hen the solution, such as the core [...] is by definition Pareto-optimal, a corresponding version of the Coase Theorem is, of course, of interest only if it goes beyond the claim of Pareto optimality by asserting that the physical resource allocation component produced by a given solution (equilibrium) is, in the absence of transaction costs, invariant with respect to differences in institutional arrangements such as liability rules (as represented, e.g., by endowments), while the money component can vary with rights assignment. (Hurwicz 1995, 50-1, his emphasis; see also Chipman and Tian 2012)

(ii) The 'Coase theorem' that assumes efficient bilateral bargaining is then used by some of the authors who defend it to bring to light the consequences of the efficiency assumption. While the circularity of this statement of the 'theorem' is a real problem for some (Regan 1972; Cooter 1982; Veljanovski 1982; Coleman 1984; Farrell 1987; Schweizer 1988; Usher 1998) who hence turn towards other statements or reject the 'Coase theorem' altogether - the circularity is on the contrary acknowledged by others (Calabresi 1968; Medema 1999). Coase's insight, and thus that of the 'theorem', would then lie in their bringing to light the consequences of the efficiency assumption. Mixing assumption and conclusion, some authors thus transform the assumption that mutually beneficial negotiations take place into a result asserted by the 'Coase theorem'. This is what appears in the statement of the 'theorem' given in the eponymous article of The New Palgrave of Law and Economics: 'When property rights are well defined and transaction costs are zero, agents with interdependent objective functions will cooperate to maximize their aggregate surplus' (De Meza 1998, 270). ${ }^{23}$ This is also how Buchanan (1988, 9) states the 'theorem': 'If ownership rights are well defined and legally protected, and if no restrictions exist, individuals will act so as to exploit all of the opportunities from exchanges among rights independently of the pattern of ownership.' And because he believes that mutually beneficial agreements are signed, he refers several times to 'the self-evident character of [this] Coasian proposition' (ibid.). Stigler $(1989,631)$ gives another good example: 'Ronald Coase taught us, what of course we should already have known, that when it is to the benefit of people to reach an agreement, they will seek to reach it.' Lastly we may cite a more recent example, by Anderlini and Felli, for whom the 'theorem' 'guarantees that, if property rights are fully allocated, economic agents will exhaust any mutual gains from trade. Fully informed rational agents, unless they are exogenously restricted in their bargaining opportunities, will ensure that there are no unexploited gains from trade' (2001, 377, their emphasis). ${ }^{24}$ In all these statements,

\footnotetext{
${ }^{23}$ The author adds: 'The notion that trade leads to efficient resource allocation has a long history. What Coase does is to draw out some of the implications of this standard doctrine for concrete issues of economic organization. The results come as a shock' (De Meza 1998, 280).

${ }^{24}$ Some maintain that this efficiency of bargaining applies even when property rights are not defined (Usher 1998, 7-8) or even in domains other than externalities - for example to solving the problems posed by monopolies (Demsetz 1968, 33; Calabresi 1968, 70).
} 
the conclusion of the 'Coase theorem' is not the efficiency of the result of the trade but the exhaustion of the gains from trade (in the absence of transaction costs), which is, in fact, assumed.

The interest of this version lies in the fact that it stresses another possibility for solving disagreements that was not taken into account by economic theory: 'Yet the Coase theorem is much more than simplistic overoptimism or circular reasoning. Organized markets in standardized commodities are not the only institutions for economists to analyze. People can be ingenious in seeking to improve their lot, and even when markets fail some hope remains for cooperation and efficiency' (Farrell 1987, 125-6). In other words, the 'theorem' may be '[i]nterpreted as a general reminder that the economy runs on a mixture of price-taking and deal-making' (Usher 1998, 10).

(iii) As a last heuristic role, this 'Coase theorem' leads to redefining Pareto-optimal situations given transaction costs. The circularity that marks this 'theorem' is closely linked to that of the transaction-costs notion: the 'theorem' states that mutually beneficial agreements are signed in the absence of transaction costs and transaction costs are defined as the only factor that can impede a mutually beneficial agreement. With this version, transaction costs came to be defined as everything that prevents the 'Coase theorem' from holding (e.g., Allen 2015, 381). In the article 'Transaction Costs' of The New Palgrave, the definition of the transaction costs as any obstacle to Paretian optimality is ultimately based on a circular 'Coase theorem':

[A]ny deviations from Pareto-optimality can be attributed to transaction costs, because in their absence all opportunities for Pareto-superior contracts would be realized. This is the so-called "Coase theorem" (Coase, 1960). [...] [I]t has often been pointed out that the underlying definition of transaction costs may be tautological: Whatever produces deviations from Pareto-optimality is implicitly interpreted as a transaction cost. (Niehans 1987, 678)

In this framework, since only transaction costs may prevent a mutually beneficial exchange from occurring, externalities are only the symptom of transaction costs. The conceptual category that prevents efficiency is no longer that of externality, but of transaction costs, such as is particularly clear with Dahlman $(1979,142)$ :

Ultimately, the relevance of externalities must lie in the fact that they indicate the presence of some transaction costs. For if there were no costs of transacting, then the potential Pareto improvement could be realized by costless bargaining between self-interested economic agents. [...] The conclusion is thus unambiguous: in the theory of externalities, transaction costs are the root of all evil. But for transaction costs, such perversions of the invisible hand could not even occur much less persist.

The externality concept is therefore 'void of any positive content' (ibid., 143).

From this definition of transaction costs or from this statement of the 'Coase theorem', there follows a redefinition of the constraints against which the optimality of an existing situation is judged. The Pareto-improving exchange of the zero-transaction-costs world, if it does not take place because of being too costly, is in fact not Pareto-improving given transaction costs. In 'The pointlessness of Pareto: Carrying Coase further', Calabresi (1991) notes that if 
transaction costs are understood as production costs, then 'no less than existing technology, [they] define what is currently achievable in any society - the Pareto frontier. It follows that any given society is always or will immediately arrive at a Pareto optimal point given transaction costs' (ibid., 1212, his emphasis). Consequently, 'what is is efficient' (ibid., 1216), even if transaction costs are positive and even high. ${ }^{25}$ One therefore cannot reject a social state A by pretending that there would exist another Pareto-superior social state, B, since, if this were the case, agents would already be in this B state. In this sense, 'the Pareto criterion is of no general use as a normative guide' (ibid.).

This interpretation of Pareto-optimality given transaction costs encounters two problems. The first is well known: it legitimates any existing situation as optimal; notions of efficiency and transaction costs are being interpreted in a circular way (Mishan 1971a; 1971b; 1974; Samuels 1974). The second problem is that such an interpretation of efficiency ultimately contradicts the 'Coase theorem', since the assumption of zero transaction costs is no longer required to assert that the result is efficient: '[A]ny starting point will be, or will immediately lead to, an efficient end point, even with transaction costs' (Calabresi 1991, 1215, his emphasis). It could be argued that the 'theorem' is therefore a robust result, but it remains that this reasoning is internally inconsistent for the following reason. After having defined transaction costs as any obstacle to efficiency, these authors conclude that all is efficient, even in the presence of transaction costs. ${ }^{26} \mathrm{We}$ find a perfect example of this reasoning in Dixit and Olson (2000), of which the main elements are as follows:

[T] he most basic claim of what has come to be called the Coase Theorem is that only transaction (or bargaining) costs can prevent voluntary bargaining from attaining Pareto-efficient outcomes. The theorem can be fairly stated as follows: "If transaction costs are zero, rational parties will necessarily achieve a Paretoefficient allocation through voluntary transactions or bargaining." [...]

[T]ransaction costs must be taken into account in defining the Pareto frontier. [...] If the familiar Coase theorem is true, it must also be true that rational parties in an economy will make all those trades in private goods, and all those bargains to internalize externalities [...] that bring positive net gains - that is, gains greater than the transaction costs needed to realize them. [...] Thus, if the Coase Theorem is true, so is a "super Coase Theorem," namely that "rational parties will necessarily achieve a Pareto-efficient allocation through voluntary transactions or bargaining, no matter how high transaction costs might be." (ibid., 310-1, their emphasis in bold, mine in italics)

\footnotetext{
25 Demsetz (1964; 2011) and Zerbe and McCurdy (1999) are also representative of this school. On Demsetz and the 'Coase theorem', see Marciano and Medema (2011) and Medema (2013).

${ }^{26}$ Nevertheless, Coase's own analysis of externalities cannot be blamed for these difficulties of circularity and inconsistency, since his conception of optimality is different. When Coase compares different allocations of property rights, he does write that '[o]ne arrangement of rights may bring about a greater value of production than any other. But unless this is the arrangement of rights established by the legal system, the costs of reaching the same result by altering and combining rights through the market may be so great that this optimal arrangement of rights, and the greater value of production which it would bring, may never be achieved' (Coase 1960, 16, my emphasis). In other words, one allocation of rights enables an optimal result and, if it is not selected by the judge, or not reached by the exchange due to its being too costly, then the situation remains suboptimal. Coase retains the reference to an ideal world and to its Pareto optimality.
} 
This reasoning that follows the circular statement of the 'Coase theorem', however debatable, is interesting in that it suggests that the categories of costs or of failures identified by economic theory result in fact from the theoretician's choices. By specifying the costs, the constraints, and the possibilities, the economist can select which social states will be said to be, supposedly neutrally, Pareto superior. This is what Calabresi (1991) wants to show:

$[\mathrm{O}]$ nce liberated from the misperception that some predetermined abstract categories of costs are in some sense "unreal" or "mere inefficiencies," obviously to be overcome, while others, defined equally abstractly, can only be conquered by costly or risky processes like "innovations," we can get down to the real job of deciding which impediments to a better life (which barriers to movements of the frontier) seem to be most worth attacking and which, for the moment, appear not to be worth the effort. (ibid., 1219)

\section{The normative role: an optimistic reading of the negotiation}

The normative role on which I now focus refers to the fact that this version of the Coase theorem conveys an optimistic view of the exchange. As I will stress, the critical and heuristic roles identified above rest upon the assumption of efficiency of bilateral bargaining. ${ }^{27}$ In other words, these roles are based upon a world vision that accompanies them and that is particularly optimistic regarding the ability of agents to agree on a surplus distribution, a belief that the desire for exchange will prevail over the conflict about the surplus distribution. To stress the optimism that characterizes the efficiency assumption and that is necessary to ground these roles, I shall contrast the cooperative with the non-cooperative formalizations of the 'Coase theorem'. This last, more pessimistic, formalization insists on the necessity of solving this conflict, and with it the roles of the 'theorem' disappear.

\subsection{Formalizing the pessimistic view of bargaining}

Because they specify a negotiation process, non-cooperative formalizations (statement NC-BB of Table 1) save the 'theorem' from the circularity problem. This is the case for Arrow's 1979 article, which opened the doors to the formalization of the 'Coase theorem' with noncooperative games, and partly led the debate to focus on the issue of information.

Arrow stresses that the validity of the Coasean argument depends on the information of the agents: 'What is not always recognized is that this argument depends crucially on the unstated assumption that every player knows every other player's payoff (utility, profit, whatever) as a function of the strategies played' (ibid., 24). The criticisms of the 'Coase theorem' that rest upon incomplete information would then be numerous throughout the 1980s (for those who include the information problems in the transaction costs, this is not literally a criticism): we can cite Samuelson 1985, Farrell 1987, Schweizer 1988, Rob 1989, Illing 1992, McKelvey and Page 1999. ${ }^{28}$ The stronger result emanates from McKelvey and Page (2002)

\footnotetext{
${ }^{27}$ The 'Coase theorem' rests on numerous other normative assumptions, stressed, among many others, by Mishan (1971a, 1971b, 1974), Samuels (1974), Coleman (1984) and Halpin (2007; 2011), and ranging from the definition of welfare to technical assumptions to the primacy of economics over law. These are beyond the scope of this study.

${ }^{28}$ The information failures are often included in the costs of transaction, for example, in Illing (1992) or Dahlman (1979) or - but without any reference to this debate - in Hovenkamp (1990, 787): 'Zero transaction costs implies
} 
who generalize the impossibility theorem of Myerson and Satterthwaite (1983) to the bilateral negotiation of a property right: with incomplete information, there is no non-cooperative negotiation procedure that results in an efficient Bayes-Nash equilibrium. ${ }^{29}$

Some of these articles demonstrate a 'Coase theorem' that is valid with complete information (Arrow 1979; Schweizer 1988) or suggest that it could be demonstrated (Farrell 1987; Illing 1992; Hahnel and Sheeran 2009). ${ }^{30}$ Since these non-cooperative formalizations of the 'Coase theorem' mainly bring to light the inefficiency of the result as soon as information is incomplete, the complete information assumption is often understood as sufficient for the validity of the 'theorem'. While some of these authors also insist on the necessity of finding the 'right' rules of the game ${ }^{31}$, we have seen a diffusion of the idea that this literature has shown that the assumption of complete information would be sufficient for the 'Coase theorem' to hold. For example, in their review of this literature, Medema and Zerbe $(2000,851)$ sum up this debate as follows: 'If parties have full information about each other's utility (or profit or production and cost) functions, the Coase Theorem will hold'. These models indeed seem to formalize Regan's (1972) and Veljanovski's (1982) intuition that complete information would enable an elimination of strategic behaviour because it makes threats non-credible - threats into which are wrongly assimilated all strategic behaviour. ${ }^{32}$ However, while the authors who used game theory argued that the complete information assumption was necessary for the 'Coase theorem' to hold, it is to be stressed that their models emphasize the necessity of another assumption (which is conjointly sufficient with complete information): the existence of an efficient rule of surplus distribution.

Take the example of a formalization with a take-it-or-leave-it procedure, or ultimatum game, like the one used by Arrow (1979). ${ }^{33}$ With such a procedure, the player who makes the offer proposes an allocation (level of externality and amount of payment) that maximizes her own utility under the constraint that this allocation is just sufficient for the second player to accept it. If information is complete, then the level of externality that is reached is socially optimal. What about distribution? With this procedure, the player who makes the offer, whether she emits or receives pollution, and whether she owns or not the property right, takes all the surplus of the exchange. The ultimatum procedure is in this sense a rule of the surplus distribution: the offering player takes it all. And this rule is efficient since it allows the sharing

perfect information, since imperfect information is simply a cost of bargaining' (see also Ellickson 1989, 615). As stressed by Medema and Zerbe (2000, 857), this definition of transaction costs eliminates the criticism based on information problems.

${ }^{29}$ McKelvey and Page (1999) generalize this result to a divisible good (the property right), and utility functions that are not linear with respect to the quantity of this good, but are still quasi-linear with respect to the moneygood.

${ }^{30}$ Samuelson (1985) and McKelvey and Page (1999) assimilate non-cooperative games to incomplete information and hence do not propose any formalization of the 'Coase theorem' in the non-cooperative framework and with complete information.

31 'Right', for Schweizer $(1988,257)$, in the sense that they enable one to describe the situation: 'The crucial question [...] hinges [...] on what would be accepted as a reasonable noncooperative game to capture the features of a given situation'; or, for Arrow $(1979,27)$, that they enable one to obtain an efficient equilibrium: '[T] problem is to devise a noncooperative game whose equilibrium point (in the sense of Nash) is an efficient allocation of resources.'

${ }^{32}$ The 1970s debate on extortion had also this role, but this was before the non-cooperative formalization. On this debate, see Medema 2015.

${ }^{33}$ It is taken up, among others, by Schweizer (1988) and in the textbook by Mas-Colell, Whinston and Green (1995). 
of all the surplus. It is true that this model does prove that we can reach efficiency with complete information, but only because we have specified a rule of the game that results in an efficient distribution of the surplus (efficient in the sense that agents share the totality of the surplus). As demanded by Paul Samuelson, we have specified how agents will divide the surplus, and we have designed this rule such that it divides the totality of the surplus, hence we have guaranteed that the process of negotiation leads to an efficient result. In the absence of such a distribution rule $^{34}$, and even with complete information, the distribution problem remains and may cause inefficiency. A valid and non-circular statement of the 'Coase theorem' must introduce a distribution rule, whether it emanates from arbitration or social norms.

\subsection{The roles of the 'Coase theorem' can rest only on an optimistic view of bargaining}

Does this version of the 'Coase theorem' - which explicitly assumes a rule of surplus distribution - have the same critical and heuristic roles? The answer is negative. The critical role of the 'theorem' was to put to the fore the possibility of a decentralized solution to externalities. As I will argue, the statement of the 'Coase theorem' that assumes complete information and a rule of surplus distribution would move us away from this spirit. And this is why Cooter proposes the name 'Hobbes theorem' for the following proposition, which is in fact a non-cooperative 'Coase theorem': 'Private bargaining to redistribute external costs will not achieve efficiency unless there is an institutional mechanism to dictate the terms of the contract' (Cooter 1982, 18).

On the one hand, the 'Hobbes theorem' cannot be likened to decentralization (if the distribution rule is imposed by an arbitrator $\left.{ }^{35}\right)$ :

The Coase Theorem and the Hobbes Theorem have contradictory implications for the size of government. We can see this point most clearly by considering the policy implications in the ideal world of zero transaction costs. According to the Coase Theorem, there is no continuing need for government under these conditions. Like the deist god, the government retires from the scene after creating some rights over externalities, and efficiency is achieved regardless of what rights were created. According to the Hobbes Theorem, the coercive threats of government or some similar institution are needed to achieve efficiency when externalities create bargaining situations, even though bargaining is costless. Like the theist god, the government continuously monitors private bargaining to insure its success. (ibid., 19)

On the other hand, and even if it were interpreted as decentralized, the non-cooperative statement of the 'Coase theorem' makes the advantage of decentralization disappear, because it assumes complete information:

\footnotetext{
${ }^{34}$ For convenience, in what follows I will use the term "rule of the surplus distribution" or "distribution rule" for a rule of the game resulting in an efficient distribution (this is the case, for example, for the rule of the ultimatum game).

${ }^{35}$ It is, however, possible to consider that this rule is not imposed from an arbitrator, but is 'chosen' by the agents (even if still imposed by society in a sense): the experiments with the 'Coase theorem' partly display how some distributions are selected under the influence of the design and instructions (see Bertrand 2014).
} 
If every agent has a complete model of the economy, the hand running the economy is very visible indeed.

Indeed, under these knowledge conditions, the superiority of the market over centralized planning disappears. Each individual agent is in effect using as much information as would be required for a central planner. This argument shows the severe limitations in the argument that property rights suffice for social rationality even in the absence of a competitive system (Coase 1960). (Arrow 1986, S392) ${ }^{36}$

The critical role of the 'theorem' can therefore rest neither upon a statement that requires a distribution rule (NC-BB statement), nor, as argued above, upon a statement that calls on the perfect competition model (PC statement); it is therefore based on the statement that assumes efficient bilateral bargaining (statement C-BB). ${ }^{37}$ This is also the case with the heuristic roles identified above, all of which came from the circular version of the 'Coase theorem'.

It is also from this latter version that the predictive and prescriptive statements usually associated with the 'Coase theorem' are inferred.

First, some predictions are inferred from the 'Coase theorem', which transform it into an empirical proposition, and they are tested. The 'theorem' in itself, however, is not an empirical but a logical proposition (Medema 2017b, 40), and it is all the less testable in that, since transaction costs are never nil, it does not apply to the real world. What is tested is a 'generalized Coase theorem', according to which, if the gain from a transaction over a right is greater than its cost, then the transaction takes place (Bertrand 2011, 40). Now, in the main empirical tests of the 'Coase theorem', Cheung (1973) and Ellickson (1986) explain their observations by the idea that a mutually satisfactory exchange is struck if its gains are greater than its costs, rather than test this idea; they are led to justify what they observe as rational, given transaction costs (which of course are not measured) (Bertrand 2011). The predictions associated with the 'theorem', and hence in a sense its predictive role, are therefore usually deduced from a version that assumes the efficiency of bilateral bargaining. ${ }^{38}$

Secondly, some prescriptive consequences are also inferred from the 'theorem', which is not prescriptive in itself, and all the less so since, once more, it does not apply to real situations in which transaction costs are never nil (Medema 2017b, 40 and 61). These 'normative Coase theorems' tell us to reduce transaction costs and legal obstacles to the exchange, and to identify the legal rules and remedies that reproduce the result of the zerotransaction-costs world or approach it. ${ }^{39}$ These prescriptions associated with the 'theorem', and hence its prescriptive role, are again inferred from a version that assumes the efficiency of bilateral bargaining:

- The lowering of transaction costs is efficient only if it is thought that it causes a lowering of strategic problems. On the contrary, those who emphasize strategic behaviour stress that

\footnotetext{
${ }^{36}$ Medema $(1999,217)$ stresses the same point: '[T] he same costlessly available information that allows the Coase theorem to work its magic in a market context would also allow government to efficiently resolve externalities using Pigovian instruments.' See also Farrell 1987.

${ }^{37}$ Since the cooperative 'Coase theorem' is circular, it retains its critical role only if it is thought that economic theory makes this same assumption (which seems to be the case, for example, for Medema and Zerbe 2000 and Demsetz 2011).

38 See also the statement experimentally tested by Hoffman and Spitzer 1982, mentioned above.

${ }^{39}$ On the 'normative Coase theorem', see also Medema 1999, Parisi 2008, Luppi and Parisi 2011.
} 
lowering transaction costs may encourage them (for then they are no longer costly) (Cooter 1982, 23), and that it is better to lower uncertainty (Veljanovski 1982).

- As for the second prescription ('mimic the market'), it is linked to the nature of the result (optimality) and not to the process that leads to it; therefore this prescription generally lies also on the circular bargaining version of the 'theorem'.

What appears in contrast with the non-cooperative version of the 'Coase theorem' is that behind the cooperative version lies an optimistic view of the market, that is of the agents' ability to find an agreement or solve the distribution problem. The 'theorem' statement that is circular (and hence its roles) makes sense only if the authors who select it think it describes human nature, at least to some extent. Farrell stresses: 'Of course, it is a tautology that if people negotiate efficiently then every outcome will be efficient (else people would negotiate something better). The Coase theorem is important only if we believe that efficient negotiation is likely' (1987, 113, his emphasis). On the contrary, it can be thought that an institution other than that of property rights is needed for an exchange to take place, a rule of the surplus distribution. To parallel the opposition between a pessimistic Coase regarding the efficiency of public intervention and an optimistic Pigou (Bertrand 2010), we see here an opposition between a vision of the world, associated with Coase, that is optimistic regarding agents' ability to realize mutually beneficial agreements, and another, which Cooter associates with Hobbes, and which would be pessimistic:

The bargaining version of the Coase Theorem takes an optimistic attitude toward the ability of people to solve this problem of distribution. The obstacles to cooperation are portrayed as the cost of communicating, the time spent negotiating, the cost of enforcing agreements, etc. These obstacles can all be described as transaction costs of bargaining. Obviously, we can conceive of a bargaining game in which these costs are nil.

A pessimistic approach assumes that people cannot solve the distribution problem, even if there are no costs to bargaining. According to this view, there is no reason why rationally self-interested players should agree about how to divide the stakes. The distribution problem is unsolvable by rational players. (Cooter 1982, 17) ${ }^{40}$

This is the optimistic vision of 'The problem of social cost' that does legitimate, in Hurwicz's $(1995,63)$ opinion, the formalization of the 'theorem' with a cooperative solution concept: 'It is, of course, not beyond the bounds of imagination that in this situation, in effect one of bilateral monopoly, a non-optimal solution might be viewed as realistic. But the spirit of Coase's approach is that the parties will somehow arrive at a Pareto-optimal solution.' This world vision, this belief in the agents' ability to exhaust gains from trade, thus determines the critical and heuristic roles of the 'Coase theorem', and even the predictive and prescriptive roles of some of its consequences. Dahlman $(1979,156)$, for instance, links this belief with one of

\footnotetext{
${ }^{40}$ Others prefer to oppose Coase with Machiavelli: 'Human history is a record of the tension between the way of Niccolo Machiavelli and what might be called the way of Ronald Coase. According to Coase's Theorem, people will never pass up an opportunity to cooperate by means of mutually advantageous exchange. What might be called Machiavelli's Theorem says that no one will ever pass up an opportunity to gain a one-sided advantage by exploiting another party' (Hirshleifer 2001, 10-1).
} 
the heuristic roles, namely the disappearance of the notion of externality that follows from his version of the 'theorem':

The conclusion is rather startling: transaction costs per se have nothing to do with externalities. What is involved is a value judgment: if you believe that markets internalize everything, you will believe that externalities do not exist; on the other hand, if you believe that markets do not internalize side effects, you will believe in the persistence of externalities as deviations from an attainable optimum. This is not science; it is metaphysics: value judgments and political goals will enter into the determination of whether externalities occur in our world. [...]

It is thus doubtful whether the term "externality" has any meaningful interpretation, except as an indicator of the political beliefs and value judgments of the person who uses (or avoids using) the term.

The criticism of public intervention in the presence of so-called market failures, the heuristic allowed by the efficiency assumption, as well as the predictions and policy prescriptions inferred from the 'theorem', rest upon its prevailing statement, that which assumes the efficiency of bilateral bargaining and which hence lies upon an optimistic belief in the agents' ability to strike mutually satisfactory bargains.

\section{Concluding remarks}

There exist several ways of envisaging the internalization of externalities by the market, which correspond to different statements of the 'Coase theorem':

\begin{tabular}{|c|c|c|c|}
\hline & \multicolumn{3}{|c|}{ The modes of internalizing externalities by exchange } \\
\hline & Perfect competition (PC) & Bilateral ba & lining (BB) \\
\hline Assumption & $\begin{array}{l}\text { Perfect competitive } \\
\text { market } \\
\text { (Arrow 1969) }\end{array}$ & $\begin{array}{l}\text { Exhaustion of gains from } \\
\text { trade } \\
(\text { Coase 1960) }\end{array}$ & $\begin{array}{l}\text { Complete information } \\
\text { and rule of negotiation } \\
\text { leading to an efficient } \\
\text { distribution } \\
\text { (Arrow 1979) }\end{array}$ \\
\hline Formalization & $\begin{array}{l}\text { Introduction of } \\
\text { personalized } \\
\text { externality- } \\
\text { commodities in the } \\
\text { Arrow-Debreu model }\end{array}$ & $\begin{array}{l}\text { Cooperative games } \\
(\mathrm{C}-\mathrm{BB})\end{array}$ & $\begin{array}{l}\text { Non-cooperative games } \\
\text { (NC-BB) }\end{array}$ \\
\hline & & \begin{tabular}{cc} 
& \multicolumn{1}{c}{ 3 roles: } \\
- & Critical \\
- & Heuristic \\
- & Normative
\end{tabular} & \\
\hline
\end{tabular}

Table 1: Classification of the statements of the 'Coase theorem'

The formalization with perfectly competitive markets (PC) shows that the first theorem of welfare economics can be extended to externalities (with some restrictions due to non- 
convexities), but is both too far from the letter of 'The problem of social cost' (which describes price-makers agents) and from its spirit (which proposes a decentralized solution) to be recognized as a valid interpretation of the 'theorem'. It is Arrow (1969) who formalizes this solution to better stress its unrealism. The formalization of the exchange that best fits Coase's article is that of a bilateral and cooperative game of bargaining (C-BB). Interpreted as such, the 'theorem' denies that the heavy assumptions of the perfect competition model are necessary to conclude that the result of decentralized exchanges is efficient, but it assumes that the result of bargaining is optimal, and hence it is circular. The nature of this belief was underlined by contrasting this version with the third one. When bargaining is formalized as a non-cooperative game (NC-BB), then complete information must be assumed, as well as rules of the game that lead to an efficient distribution of the surplus, but this version is, again, not in the spirit of Coase's article. The present typology of the statements of the 'Coase theorem' joins the typology of the possible formalizations of the Coasean idea put forward by Schweizer (1988): perfect competition, cooperative bargaining game, non-cooperative bargaining game. ${ }^{41}$

We can understand the importance of the prevailing cooperative statement of the 'theorem' - which is circular - once we acknowledge the three roles it has in microeconomics.

The first, critical, role has just been recalled: this 'Coase theorem' rejects the necessity of the perfect competition model. More generally, it rejects welfare economics and the necessity of a public solution to market failures. It loses its critical strength since it is circular; but its advocates seem to think that it translates the economists' vision of the market, from which they would not draw all the consequences. One must look for the interest of this 'theorem', even though it is circular, in its consequences - heuristic, and then normative.

For those who defend the cooperative 'Coase theorem', its insight lies in the way it seriously takes into account the assumption of efficient negotiations by bringing its consequences to completion. It underlines that the obstacles to efficiency are ultimately due to transaction costs and not to so-called market failures. This point of view leads to defining transaction costs as everything that prevents optimality, and thus to characterizing every existing situation as optimal. This is one of the heuristic roles of this 'theorem'. The assumption that mutually advantageous exchanges take place becomes the true result of the 'Coase theorem.'

Thus, the normative role of this 'theorem' finally appears, because of this legitimation of the status quo that it bears in its heart, and of the fundamental optimism - the belief in the exhaustion of gains from trade - on which it rests. These roles are indeed based upon the idea of the realization of efficient agreements. Postulating its own result, the 'theorem' is fundamentally optimistic: it asserts that the problem of surplus distribution is solved by rational agents when it is in their interest to do so. We could as well argue the contrary, as expressed by Cooter's 'Hobbes theorem'. Neither of these assertions can be proved, as Cooter $(1982,28)$ recognized: 'The Coase Theorem and the Hobbes Theorem are illuminating falsehoods. The

\footnotetext{
${ }^{41}$ Other classifications of the 'Coase theorems' exist. Those of Zerbe (1980), Veljanovski (1982) and Medema and Zerbe (2000) are sometimes ambiguous on what they call perfect competition and bargaining. Cooter's (1982) classification is closer to mine (without the distinction between cooperative and non-cooperative games). Regarding the possible formalizations of the Coasean idea, Hurwicz (1995) also distinguishes the competitive equilibrium and cooperative solution concepts, and McKelvey and Page (1999), for their part, separate cooperative (which include the perfect competition solution) and non-cooperative games.
} 
Coase Theorem is false because the final obstacle to private noncompetitive bargains is the absence of a rule for dividing the surplus, not the cost of bargaining. [...] The Hobbes Theorem is false because bargainers moderate their demands in order to increase the likelihood of agreement.'

The critical, heuristic, and normative roles - which are the analytical issues in the controversy over the meaning of the 'Coase theorem' - therefore rest on the cooperative bargaining version. In this version, the assumption becomes the conclusion. Its advocates forget its circular dimension, and assign demonstrative power to a conclusion that in fact possesses none. At root, we can see this as an expression of these advocates' belief that this assumption does indeed describe the world - and thus as an expression of what I have called their optimism. This is the price to be paid when the Arrow-Debreu conception of exchange and its price-taker agents are abandoned.

\section{References}

AivAZIAN V. A. and CALLEN J. L. 1981. "The Coase theorem and the empty core", Journal of Law and Economics, 24(1), 175-81.

Aivazian V. A. and CALLEN J. L. 2017. "The Coase theorem and theory of the core", in A. Marciano and G.B. Ramello (eds), Encyclopedia of Law and Economics, New York, Springer, DOI 10.1007/978-1-4614-7883-6_623-1

ALLEN D. W. 1991. "What are transaction costs", Research in Law and Economics, 14, 1-18.

ALLEN D. W. 2015. "The Coase theorem: coherent, logical, and not disproved", Journal of Institutional Economics, 11(2), 379-90.

ANDERLINI L. AND FELLI L. 2001. "Costly bargaining and renegotiation”, Econometrica, 69(2), 377-411.

ARROW K. J. 1969. "The organization of economic activity: Issues pertinent to the choice of market versus non market allocation", in Joint Economic Committee (ed.), The Analysis and Evaluation of Public Expenditures: The PPB System, vol. 1, Washington, DC, Government Printing Office, 47-64. Repr. in Collected Papers of Kenneth J. Arrow, vol. 2: General Equilibrium, Oxford, Basil Blackwell, 1983, 133-55.

ARROW K. J. 1979. "The property rights doctrine and demand revelation under incomplete information”, in M. J. Boskin (ed.), Economics and Human Welfare: Essays in Honour of Tibor Scitovski, New York, Academic Press, 23-39.

ARROW K. J. 1986. "Rationality of self and others in an economic system", The Journal of Business, 59(4), Part 2, S385-99.

ARRow K. J. and DEBREU G. 1954. "Existence of an equilibrium for a competitive economy", Econometrica, 22(3), 265-90.

BARZEL Y. 1989. Economic Analysis of Property Rights, Cambridge, Cambridge University Press.

BERTA N. 2000. Origines et fondements de la représentation du marché dans la théorie de l'équilibre général concurrentiel, $\mathrm{PhD}$. thesis, University Paris 1 Panthéon-Sorbonne.

BERTA N. 2017. "On the definition of externality as a missing market", European Journal of the History of Economic Thought, 24(2), 287-318.

BERTA N. and BERTRAND E. 2014. "Market internalization of externalities: What is failing?", The Journal of the History of Economic Thought, 36(3), 331-57.

BERTRAND E. 2006. "The Coasean analysis of lighthouse financing: Myths and realities", Cambridge Journal of Economics, 30(3), 389-402.

BERTRAND E. 2010. "The three roles of the 'Coase theorem' in Coase's works", The European Journal of the History of Economic Thought, 17(4), 975-1000. 
BERTRAND E. 2011. "What do cattle and bees tell us about the Coase theorem?", The European Journal of Law and Economics, 31(1), 39-62.

BERTRAND E. 2014. “Autorisation à l'échange sur des externalités: de l'interdiction à l'obligation", Revue Economique, 65(2), 439-59.

BERTRAND E. 2019. "George Stigler, the first apostle of the "Coase theorem"”, in C. Freedman (ed.), Understanding the Enigmatic George Stigler: Extending Price Theory in Economics and Beyond, Palgrave Macmillan.

BLAUG M. 2007. "The fundamental theorems of modern welfare economics, historically contemplated", History of Political Economy, 39(2), 185-207.

Block W. E, CALlAhan. G. and BARNETT W. II 2005. "The paradox of Coase as a defender of free markets", New York University Journal of Law and Liberty, 1(3), 1075-95.

BOYD J. H. III. and CONLEY J. P. 1997. "Fundamental nonconvexities in Arrovian markets and a Coasian solution to the problem of externalities", Journal of Economic Theory, 72(2), 388407.

BuCHANAN J. M. 1988. "Economists and the gains from trade", Managerial and Decision Economics, 9(5), 5-12

Buchanan J. M. and Stubblebine W. C. 1962. "Externality", Economica, 29(116), 371-84.

CALABRESI G. 1965. "The decision for accidents: An approach to non-fault allocation of costs", Harvard Law Review, 78(4), 713-745.

CALABRESI G. 1968. "Transaction costs, resource allocation and liability rules - A comment", Journal of Law and Economics, 11(1), 67-73.

CALABRESI G. 1991. "The pointlessness of Pareto: Carrying Coase further", The Yale Law Journal, 100(5), 1211-37.

CHEUnG S. N. S. 1973. "The fable of the bees: An economic investigation", Journal of Law and Economics, 16(1), 11-33.

CHIPMAN J. S. AND TIAN G. 2012, "Detrimental externalities, pollution rights, and the 'Coase theorem"', Economic Theory, 49(2), 309-327.

COASE R. H. 1959. "The Federal Communication Commission", Journal of Law and Economics, 2, 1-40.

COASE R. H. 1960. "The problem of social cost", Journal of Law and Economics, 3, 1-44.

COASE R. H. 1974. "The lighthouse in economics", Journal of Law and Economics, 17(2), 35776.

COASE R. H. 1988. The Firm, the Market and the Law, Chicago, The University of Chicago Press.

COASE 2002. "A conversation with Ronald Coase", The intellectual portrait series, Liberty Fund video, interview with R. A. Epstein.

COLEMAN J. L. 1984. "Economics and the Law: A critical review of the foundations of the economic approach to law", Ethics, 94(4), 649-79.

CONLEY J. P. and SMith S. P. 2005. "Coasian equilibrium", Journal of Mathematical Economics, 41(6), 687-704.

COOTER R. D. 1980. "How the law circumvents Starrett's nonconvexity", Journal of Economic Theory, 22(3), 499-504 "LE?

CoOTER R. D. 1982. "The cost of Coase", The Journal of Legal Studies, 11(1), 1-33.

DAHLMAN C. J. 1979. "The problem of externality", Journal of Law and Economics, 22(1), 141-62.

DAvis O. A. and Whinston A. 1962. "Externalities, welfare, and the theory of games", The Journal of Political Economy, 70(3), 241-62.

De Meza D. 1998, "Coase theorem", in P. K. Newman (ed.), The New Palgrave Dictionary of Economics and the Law, vol. 1, London, Macmillan, 270-82. 
DEBREU G. and SCARF H. 1963. "A limit theorem on the core of an economy", International Economic Review, 4(3), 235-46.

DEMSETZ H. 1964. "The exchange and enforcement of property rights", Journal of Law and Economics, 7, 11-26.

DEMSETZ H. 1968. "The cost of transacting”, The Quarterly Journal of Economics, 82(1), 3353.

DEMSETZ H. 2011. "The problem of social cost: What problem? A critique of the reasoning of A. C. Pigou and R. H. Coase", Review of Law and Economics, 7(1), 1-13.

DESERPA A. C. 1977. "The Coase theorem: A diagrammatic presentation", Economic Inquiry, $15(4), 600-4$.

DiXIT A. and OlSON M. 2000. "Does voluntary participation undermine the Coase Theorem?", Journal of Public Economics, 76(3), 309-35.

EDGEWORTH, F. Y. 1881. Mathematical Psychics. An Essay on the Application of Mathematics to the Moral Sciences, London, Kegan Paul.

ELLICKSON R. C. 1986. "Of Coase and cattle: Dispute resolution among neighbors in Shasta County", Stanford Law Review, 38(3), 623-87.

ELLICKSON R. C. 1989. "The case for Coase and against 'Coaseanism'”, The Yale Law Journal, 99(3), 611-30.

FARRELL J. 1987. "Information and the Coase theorem", The Journal of Economic Perspectives, 1(2), 113-29.

Fox G. 2007. "The real Coase theorems", Cato Journal, 27(3), 373-96.

GONZALEZ S. and MARCIANO A. 2017. "De nouveaux éclairages sur le théorème de Coase et la vacuité du cœur", Revue d'Economie Politique, 127(4), 585-606.

HAHNEL R. and SHEERAN K. A. 2009. "Misinterpreting the Coase theorem", Journal of Economic Issues, 43(1), 215-38.

HALPIN A. 2007. "Disproving the Coase Theorem?”, Economics and Philosophy, 23(3), 32141.

HALPIN A. 2011. “Coase's World And Coase's Blackboard”, European Journal of Law and Economics, 31(1), 91-109.

HiLdENBRAND W. and KIRMAN A. P. 1988. Equilibrium Analysis: Variations on Themes by Edgeworth and Walras, $2^{\text {nd }}$ ed., Amsterdam, North-Holland, 1991.

HIRSHLEIFER J. 2001. The Dark Side of the Force: Economic Foundations of Conflict Theory, Cambridge, Cambridge University Press.

HofFMAN E. and SPITZER M. L. 1982. "The Coase theorem: Some experimental tests", Journal of Law and Economics, 25(1), 73-98.

HovenKamp H. J. 1990. "Marginal utility and the Coase theorem", Cornell Law Review, 75(4), 783-810.

HuRwicz L. 1995. "What is the Coase Theorem?", Japan and the World Economy, 7(1), 4974.

ILLING G. 1992. "Private information as transaction costs: The Coase theorem revisited", Journal of Institutional and Theoretical Economics, 148(4), 558-76.

LAFFONT J.-J. 1978. "Decentralization with externalities", European Economic Review, 7(4), 359-75.

LUPPI B. and PARISI F. 2011. "Toward an asymmetric Coase theorem", European Journal of Law and Economics, 31(1), 111-22.

MARCIANO A. 2012. "Guido Calabresi's economic analysis of law, Coase and the Coase theorem", International Review of Law and Economics, 32(1), 110-8.

MARCIANO A. 2013. "Why market failures are not a problem: James Buchanan on market imperfections, voluntary cooperation, and externalities", History of Political Economy, 45(2), 223-54. 
MARCIANO A. 2018. "Why is 'Stigler's Coase Theorem' Stiglerian? A methodological explanation", Research in the History of Economic Thought and Methodology, 36A, 127-155.

MARCIANO A. and MEDEMA S. G. 2011. "Interdisciplinarity in the early reception of 'The problem of social cost' at the University of Chicago", mimeo.

Mas-Colell A., Whinston M. D. and Green J. R. 1995. Microeconomic Theory, New York, Oxford University Press.

McKelvey R. D. and Page T. 1999. "Taking the Coase theorem seriously", Economics and Philosophy, 15(2), 235-47.

MCKelveY R. D. and PAGE T. 2002. "Status quo bias in bargaining: An extension of the Myerson-Satterthwaite theorem with an application to the Coase theorem", Journal of Economic Theory, 107(2), 336-55.

Medema S. G. 1999. "Legal fiction: The place of the Coase theorem in Law and Economics", Economics and Philosophy, 15(2), 209-33.

Medema S. G. 2009. The Hesitant Hand: Taming Self-Interest in the History of Economic Ideas, Princeton, Princeton University Press.

Medema S. G. 2011a. "A case of mistaken identity: George Stigler, 'The problem of social cost,' and the Coase Theorem", European Journal of Law and Economics, 31(1), 11-38.

MeDEMA S. G. 2011b. "The Coase theorem: Lessons for the study of the history of economic thought", Journal of the History of Economic Thought, 33(1), 1-18.

MEDEMA S. G. 2013. "Rethinking externalities: Coase's negotiation result before the 'Coase theorem", mimeo

Medema S. G. 2014a. "1966 and all that: Codification, consolidation, creep, and controversy in the early history of the Coase theorem", Journal of the History of Economic Thought, 36(3), 271-303.

MedEma S. G. 2014b. "Debating law's irrelevance: Legal scholarship and the Coase theorem in the 1960s," Texas A\&M Law Review, 2, 159-213.

MEDEMA S. G. 2014c. "Economics and institutions: Lessons from the Coase theorem", Revue Economique, 65(2): 243-61.

Medema S. G. 2014d. "Juris Prudence: Calabresi's uneasy relationship with the Coase theorem", Law and Contemporary Problems, 77(2), 65-95.

Medema S. G. 2014e. "Neither misunderstood nor ignored: The early reception of Coase's wider challenge to the analysis of externalities," History of Economic Ideas, 22(1), 111-32.

MEDEMA S. G. 2014f. "The curious treatment of the Coase theorem in environmental economics 1960-1979," Review of Environmental Economics and Policy, 8: 39-57.

MEDEMA S. G. 2015. "“A magnificent business prospect . . .' the Coase theorem, the extortion problem, and the creation of Coase theorem worlds", Journal of Institutional Economics, 11(2), 353-78.

MedEMA S. G. 2019a. "'Exceptional and unimportant'? The rise, fall, and rebirth of externalities in economic analysis", History of Political Economy, forthcoming.

Medema S. G. 2019b. "The Coase Theorem at sixty", Journal of Economic Literature, forthcoming.

Medema S. G. and SAmuels W. J. 1997. "Ronald Coase and Coasean economics: Some questions, conjectures and implications", in W. J. Samuels, S. G. Medema and A. A. Schmid (eds), The Economy as a Process of Valuation, Aldershot, Edward Elgar, 72-128.

Medema S. G. and Zerbe R. O. JR. 2000. "The Coase theorem", in B. Bouckaert and G. De Geest (eds), The Encyclopedia of Law and Economics, vol. I, Cheltenham, Edward Elgar, 83692.

MEYER R. A. 1971. "Externalities as commodities", The American Economic Review, 61(4), 736-40.

Mishan E. J. 1971a. "Pangloss on pollution", Swedish Journal of Economics, 73(1), 113-20. 
Mishan E. J. 1971b. "The postwar literature on externalities: An interpretative essay", Journal of Economic Literature, 9(1), 1-28.

MiSHAN E. J. 1974 "The economics of disamenity", Natural Resources Journal, 14(1), 55-86. MYERSON R. B. and SATTERTHWAITE M. A. 1983. "Efficient mechanisms for bilateral trading", Journal of Economic Theory, 29(2), 265-281.

NiEHANS J. 1987. "Transaction costs", in J. M. Eatwell, M. Milgate and P. Newman (eds), The New Palgrave: A Dictionary of Economics, vol. 4, London, MacMillan, 676-9.

PARISI F. 2008. "Coase theorem" in L. E. Blume and S. N. Durlauf (eds), The New Palgrave Dictionary of Economics, $2^{\text {nd }}$ ed., New York, Palgrave MacMillan.

PigOU A. C. 1932. The Economics of Welfare, $4^{\text {th }}$ ed., London, Macmillan, 1948.

POLINSKY A. M. 1979. "Controlling externalities and protecting entitlements: Property right, liability rule, and tax-subsidy approaches”, Journal of Legal Studies, 8(1), 1-48.

PosNer R. A. and PARISI F. (eds) 2013. The Coase Theorem, Aldershot, Edward Elgar.

RANDALL A. 1974. "Coasian externality theory in a policy context", Natural Resources Journal, 14(1), 35-54.

REGAN D. H. 1972. "The problem of social cost revisited", Journal of Law and Economics, 15(2), 427-37.

RoB R. 1989. "Pollution claim settlements under private information", Journal of Economic Theory, 47(2), 307-33.

SAMUELS W. J. 1974. "The Coase theorem and the study of Law and Economics", Natural Resources Journal, 14(1), 1-33.

SAMUELSON P. A. 1967. "The monopolistic competition revolution", in R. E. Kuenne (ed), Monopolistic Competition Theory: Studies in Impact; Essays in Honour of Edward H. Chamberlin, New York, Wiley. Repr. in R. C. Merton (ed.), The Collected Scientific Papers of Paul A. Samuelson, vol. 3, Cambridge, MIT Press, 1972, 18-51.

SAMUELSON P. A. 1995. "Some uneasiness with the Coase Theorem", Japan and the World Economy, 7, 1-7.

SAMUELSON W. 1985. "A comment on the Coase theorem”, in A. E. Roth (ed.) Game-theoretic Models of Bargaining, Cambridge, Cambridge University Press, 599-611.

SCHWEIZER U. 1988. "Externalities and the Coase theorem: Hypothesis or result?", Journal of Institutional and Theoretical Economics, 144(2), 245-66.

STARRETT D. A. 1972. "Fundamental nonconvexities in the theory of externalities", Journal of Economic Theory, 4(2), 180-99.

Stigler G. J. 1966. The Theory of Price, $3^{\text {rd }}$ ed., New York, Macmillan.

STIGLER G. J. 1989. “Two notes on the Coase theorem", The Yale Law Journal, 99(3), 631-3.

TURVEY R. 1963. "On divergences between social cost and private cost”, Economica, 30(119), 309-13.

USHER D. 1998. "The Coase theorem is tautological, incoherent or wrong", Economic Letters, 61(1), 3-11.

VARIAN H. R. 1995. "Coase, competition, and compensation", Japan and the World Economy, 7(1), 13-27.

VELJANOVSKI C. G. 1982. "The Coase theorems and the economic theory of markets and law", Kyklos, 35(1), 53-74.

WELLISZ S. 1964. "On external diseconomies and the government-assisted invisible hand", Economica, 31(124), 345-62.

ZERBE R. O. JR. 1980. "The problem of social cost in retrospect", Research in Law and Economics, 2, 83-102.

ZERBE R. O. JR. and MCCURDY H. E. 1999. "The failure of market failure", Journal of Policy Analysis and Management, 18(4), 558-78. 